\title{
EFFECT OF PREBIOTICS, INORGANIC SALTS AND AMINO ACIDS FOR CELL ENVELOPE PROTEINASE PRODUCTION FROM LACTOBACILLUS PLANTARUM LP69
}

\author{
Fangfang Cheng ${ }^{1}$, He Chen ${ }^{1}$, Ni Lei ${ }^{1}$, Meng Zhang ${ }^{2}$, Hongchang Wan², Guowei Shu ${ }^{1 凶}$ \\ ${ }^{1}$ School of Food and Biological Engineering, Shaanxi University of Science and Technology \\ Xuefu Middle Road 6, weiyang district, 710021 Xi'an, China \\ ${ }^{2}$ Shaanxi Yatai Dairy \\ Xianyang 713701, China
}

\begin{abstract}
Background. Cell-envelope proteinases (CEPs) can improve the texture and organoleptic characteristics of dairy products, and may also cause the release of bioactive peptides, which contribute to improving the host's health. Thus, the CEPs with high activity produced by L. plantarum has great potential in the development of functional dairy products.

Methods. A single factor experiment was used to investigate the effects of prebiotics (inulin, stachyose, isomaltooligosaccharide, xylooligosaccharides, galactooligosaccharides and fructooligosaccharides), inorganic salts $\left(\mathrm{Na}_{2} \mathrm{HPO}_{4}, \mathrm{NaH}_{2} \mathrm{PO}_{4}, \mathrm{~K}_{2} \mathrm{HPO}_{4}, \mathrm{KH}_{2} \mathrm{PO}_{4}, \mathrm{CH}_{3} \mathrm{COONa}\right.$ and $\left.\mathrm{C}_{6} \mathrm{H}_{14} \mathrm{~N}_{2} \mathrm{O}_{7}\right)$ and amino acids (arginine, leucine, serine, lysine, alanine and glutamic acid) on the activity of cell envelope proteinases (CEPs), specific activity, protein content, $\mathrm{OD}_{600}$ value and $\mathrm{pH}$ in MRS broth fermented by Lactobacillus plantarum LP69.

Results. The optimum concentration of inulin $(0.7 \%)$, isomaltooligosaccharide $(0.5 \%), \mathrm{Na}_{2} \mathrm{HPO}_{4}(0.4 \%)$, $\mathrm{CH}_{3} \mathrm{COONa}(0.4 \%)$, leucine $(20 \mathrm{mg} / \mathrm{L})$, serine $(20 \mathrm{mg} / \mathrm{L})$ for $L$. plantarum LP69 was estimated with the activity of CEP in the range $17.36-21.47 \mathrm{U} / \mathrm{mL}$, protein content in the range $19.18-22.53 \mathrm{mg} / \mathrm{mL}$, specific activity in the range $0.77-1.12 \mathrm{U} / \mathrm{mg}$.

Conclusion. Inulin, isomaltooligosaccharide, $\mathrm{Na}_{2} \mathrm{HPO}_{4}, \mathrm{CH}_{3} \mathrm{COONa}$, leucine and serine are superior to other selected substances, and have a significant influence on the CEP activity and specific activity of L. plantarum LP69. This would provide a reference for further optimization of CEP-producing media of L. plantarum LP69.
\end{abstract}

Keywords: Lactobacillus plantarum LP69, cell-envelope proteinases, prebiotics, inorganic salts, amino acids, single-factor test

\section{INTRODUCTION}

Using lactic acid bacteria (LAB) in the fermentation industry has a long history that applies especially to fermented dairy products such as cheese, yogurt and milk powder. Lactobacillus is the largest genera in LAB, with the widest technological and industrial application, and is applied as probiotic culture to

Funding: the Key Research and Development Program of Shaanxi (Program No. 2018ZDCXL-NY-01-01 and 2019ZDLNY06-03), the science and technology project of Xi' an city [2017050NC/NY007(1)]. 
promote the host's health (Hammes and Hertel, 2006). The CEP, anchored on the LAB surface, is a class of extracellular proteolytic enzymes obtained easily from lactic acid bacteria. In the food industry, it is well known that cell-envelope proteinases (CEPs) can improve the texture and sensory characteristics of dairy products, as well as causing the release of bioactive health-beneficial peptides from milk protein (Tsakalidou et al., 1999). Cell-envelope proteinases - CEPs have enormous biotechnological potential and thus the production of profuse CEPs with high activity is necessary to satisfy the needs of the food industry.

Lactobacilli are extremely fastidious organisms adapted to complex growth media (Hebert et al., 2004). Not only do they need carbohydrates as an energy and carbon source, they also require nucleotides, amino acids, vitamins, salts and other nutriments for their growth and products synthesis in medium (Hebert et al., 2000). The production of CEPs from Lactobacilli is affected not only by the medium compositions but also by temperature and $\mathrm{pH}$, and these fermentation parameters may determine the yield and activity of the enzymes produced (Espeche Turbay et al., 2009). Most studies have delineated the isolation, purification and properties of CEP from some lactobacilli species (Chen et al., 2018; Laloi et al., 1991; Scolari et al., 2006). Agyei et al. (2012) optimized the batch culture conditions for CEP production from Lactobacillus delbrueckii subsp. lactis 313 and obtained maximum proteinase activity. Ren et al. (2014) explored the optimal medium components and fermentation conditions in MRS broth for CEP production by Lactobacillus acidophilus. In addition, Samartsev et al. (2000) found that $\mathrm{pH}$ and substances of the medium had a significant impact on the production of cell-wall-bound enzymes by Bifidobacterium adolescentis 94-BIM. However, there is very little literature on the optimization of media for CEP production by Lactobacillus plantarum.

Lactobacillus plantarum is distributed widely in nature, and has widespread application in foods, animal feeds, industrial production, health care and other fields for its great physiological characteristics and probiotic functions (Wu et al., 2019). In previous studies, our lab found that products of goat milk hydrolyzed by CEPs of $L$. plantarum LP69 have strong ACE-inhibitory activity and antioxidant activity (Chen et al., 2012; 2015). Therefore, in order to carry out further study of the biotechnological characteristics of CEP from the strain LP69, it is necessary to obtain CEPs with high activity by manipulating culture medium conditions. This study aimed to investigate the effect of selected prebiotics, inorganic salts and amino acids added to the MRS medium on CEP activity, specific activity and protein content of L. plantarum LP69, which provided insights for the further optimization of CEP-producing mediums.

\section{MATERIALS AND METHODS}

\section{Bacterial strain and media}

L. plantarum LP69 was obtained from the School of Food and Biological Engineering, Shaanxi University of Science and Technology. The deMan, Rogosa and Sharpe (MRS) broth was obtained from hopebiol Technology Co., Ltd. (Tianjin, China) and autoclaved at $121^{\circ} \mathrm{C}$ for $15 \mathrm{~min}$. The strain LP69 was inoculated $5 \%(\mathrm{v} / \mathrm{v})$ into MRS broth and activated for three generations at $37^{\circ} \mathrm{C}$ for $22 \mathrm{~h}$.

\section{Preparation of crude CEPs}

Different concentrations of selected substances were added to the activated strain LP69, and these were fermented in MRS medium at $37^{\circ} \mathrm{C}$ for $22 \mathrm{~h}$ under anaerobic conditions with an inoculum size of $5 \%$. Following this, the culture was centrifuged $(4500 \times \mathrm{g}, 20 \mathrm{~min}$, $4^{\circ} \mathrm{C}$ ) and the harvested cells were washed three times with $50 \mathrm{mM}$ Tris-HCL buffer solution (pH 7.8) containing $30 \mathrm{mM} \mathrm{CaCl}_{2}$, after which the cell pellets were obtained by centrifugation $\left(4500 \times \mathrm{g}, 20 \mathrm{~min}, 4^{\circ} \mathrm{C}\right)$. A mixture of buffer (50 mM Tris-HCL buffer, $50 \mathrm{mM}$ EDTA-Na $2, \mathrm{pH}$ 7.0) and sediments was incubated at $37^{\circ} \mathrm{C}$ for $1 \mathrm{~h}$. The crude CEPs was obtained after centrifugation $\left(4500 \mathrm{r} / \mathrm{min}\right.$ for $15 \mathrm{~min}$ at $\left.4^{\circ} \mathrm{C}\right)$.

\section{Culture conditions}

A modified culture media was used in this study, which was based on the ingredients of a standard MRS-broth. This modification mainly concerned the change of inorganic salts, the addition of prebiotics and amino acids, while other components of the medium remained unchanged. The prebiotics, inorganic salts, amino acids were added to MRS broth at $0.5 \%$, $0.4 \%, 20 \mathrm{mg} / \mathrm{L}$, respectively. After being cultured with a strain LP69 at $37^{\circ} \mathrm{C}$ for $22 \mathrm{~h}$, the samples collected 
were taken out for measuring enzyme activity, protein content, specific activity, $\mathrm{OD}_{600}$ value and $\mathrm{pH}$ value, and the optimal nutrients were selected for further concentration-screening experiments under the same culture conditions.

\section{Culture pH and L. plantarum LP69 growth analysis}

The $\mathrm{pH}$ of the culture was measured with a $\mathrm{pH}$ meter (PHS-3C) and the absorbance at $600 \mathrm{~nm}$ was determined by UV spectrophotometer with version SP-756PC. The bacterial growth was measured after cultivating for $22 \mathrm{~h}$ under anaerobic conditions.

\section{Measurement of proteinase activity}

Enzyme activity was measured according to a previous study, which based on the Folin method (Chen et al., 2018).

\section{Protein quantification}

The amount of protein was estimated by means of the Bradford method (Bradford, 1976) using bovine serum albumin as a standard.

\section{Specific activity assay}

Specific activity was expressed as the number of units of enzyme activity per mg protein (Ngo et al., 2008):

$$
\text { Specific activity, } \mathrm{U} / \mathrm{mg}=\frac{\text { total enzyme activity, } \mathrm{U}}{\text { total protein, } \mathrm{mg}}
$$

\section{Statistical analysis}

Data from three replicated trials for each treatment are presented as means with standard deviation (mean $\pm \mathrm{SD}$ ). Statistical analysis was performed using the Origin 9 software package (Origin Lab Inc., Alexandria, VA, USA) and Microsoft Excel 2010 (Redmond, WA, USA). $P$-values $<0.05$ represented significant differences.

\section{RESULTS AND DISCUSSION}

\section{Effect of prebiotics on L. plantarum LP69 producing CEP}

The level of prebiotic added was a critical factor in improving the viability of lactobacillus during fermentation (Paloma et al., 2019). It can be seen from Figure 1 that when inulin or isomaltooligosaccharide was added to the medium, the CEP produced by L. plantarum LP69 had higher enzyme activity, specific activity and optical density $(p<0.05)$. Different prebiotics were added to the medium, and there was no significant change in $\mathrm{pH}$ values $(p>0.05)$. Therefore, inulin and isomaltooligosaccharide were selected for further study.
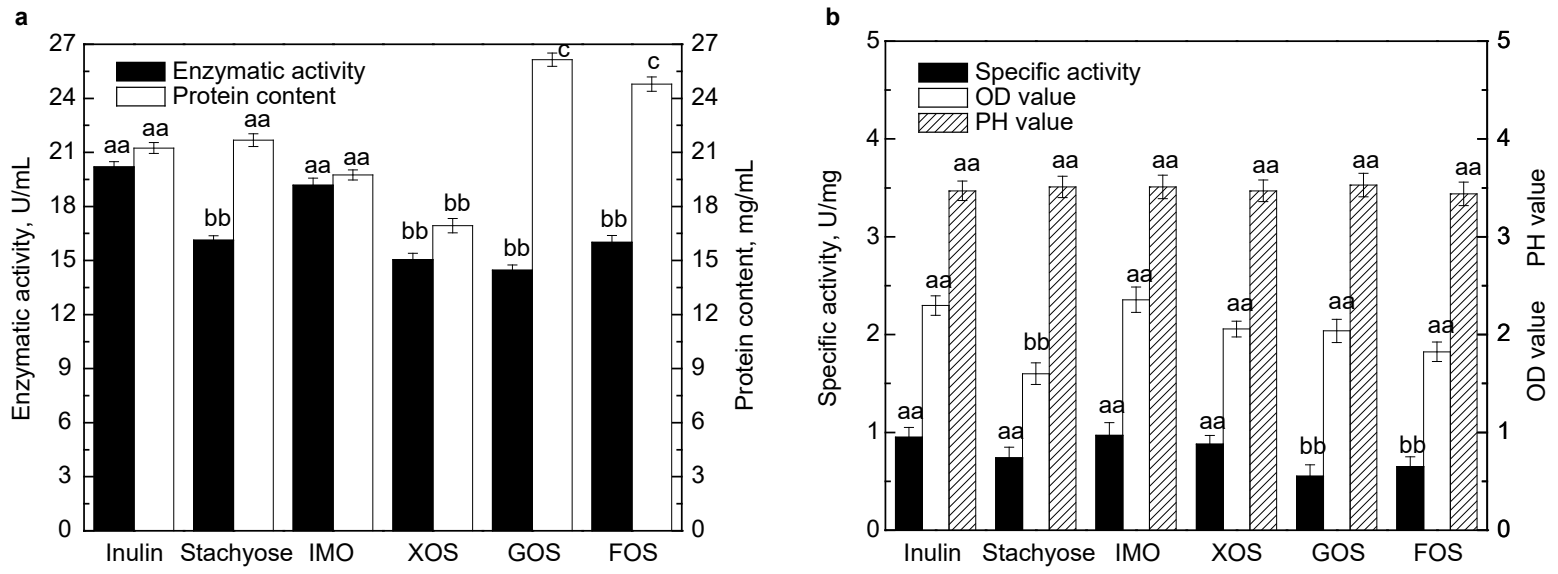

Fig. 1. The effect of different prebiotics on CEP production by L. plantarum LP69: a - enzyme activity, protein content, $\mathbf{b}$ - specific activity, $\mathrm{OD}_{600}$ value, $\mathrm{pH}$; IMO - isomaltooligosaccharide, XOS - xylooligosaccharides, GOS - galactooligosaccharides, FOS - fructooligosaccharides. Mean values relating to the same series, expressed in different letters are significantly different $(p<0.05)$ 


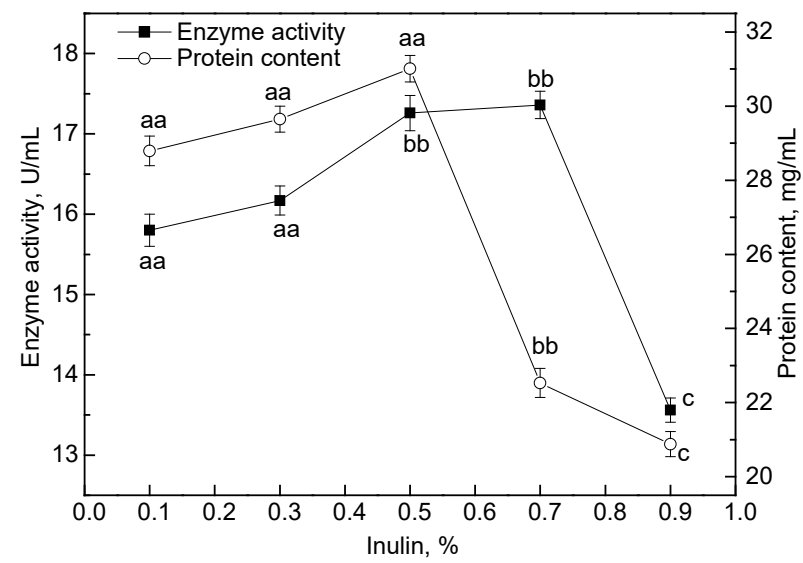

b

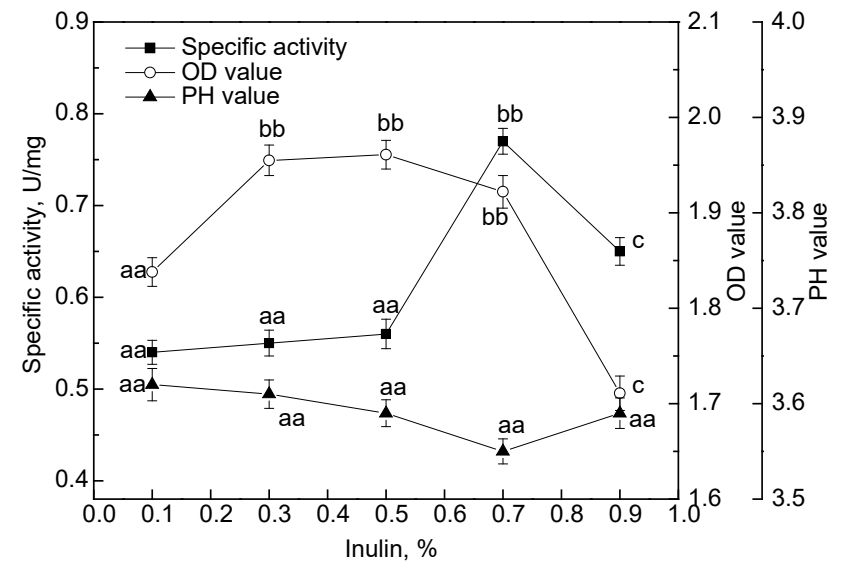

Fig. 2. The effect of inulin on CEP production by L. plantarum LP69: a - enzyme activity, protein content, $\mathbf{b}$ - specific activity, $\mathrm{OD}_{600}$ value, $\mathrm{pH}$. Mean values relating to the same series, expressed in different letters are significantly different $(p<0.05)$

The inulin was added to the MRS medium at $0.1 \%$, $0.3 \%, 0.5 \%, 0.7 \%$ and $0.9 \%$. As shown in Figure 2, as the inulin concentration increased, enzyme activity, protein content and specific activity first increased and then decreased $(p<0.05)$. The enzyme activity was highest at $17.36 \mathrm{U} / \mathrm{mL}$ at the inulin concentration of $0.7 \%$, and the specific activity was $0.77 \mathrm{U} / \mathrm{mg}$. When the inulin concentration was $0.5 \%$, the protein content reached its maximum value of $31.01 \mathrm{mg} / \mathrm{mL}$ and the OD value also reached the maximum. The $\mathrm{pH}$ value reached the lowest point at $0.7 \%$ inulin concentration, indicating that bacteria had good metabolic acid production capacity. Since the enzyme activity and specific activity were the primary indicators, $0.7 \%$ was selected as the optimum concentration of inulin.

Adebola et al. (2014) found that inulin can markedly promote the growth of lactobacilli probiotics, which was consistent with the results of this study. However, inulin in high concentrations inhibited cell growth, and the possible reason was that fructose produced by a

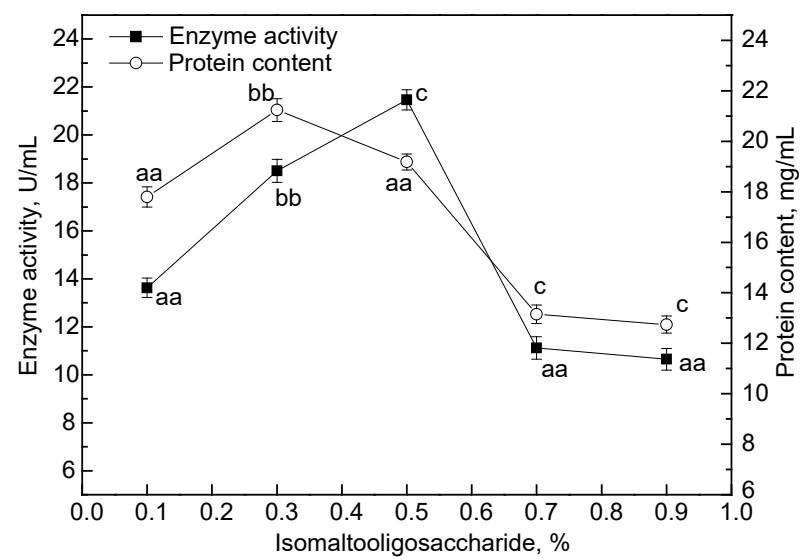

b

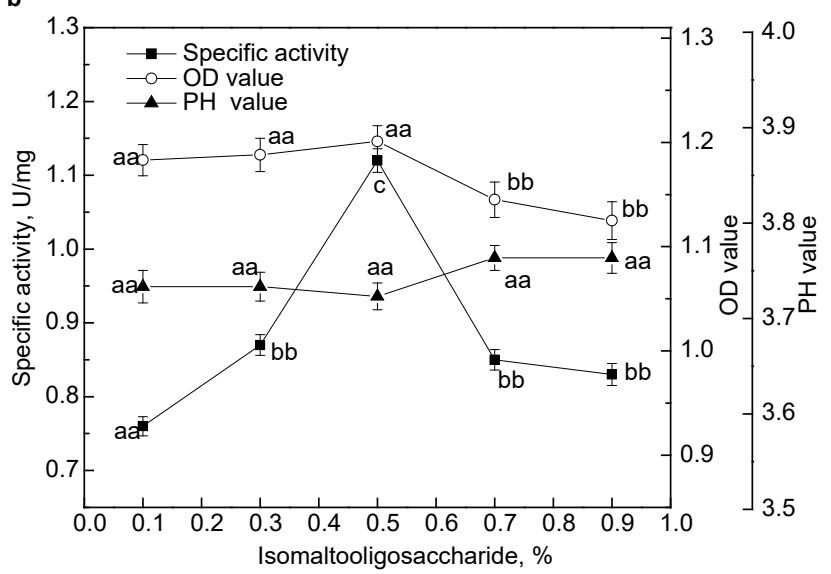

Fig. 3. The effect of isomaltooligosaccharide on CEP production by L. plantarum LP69: a - enzyme activity, protein content, $\mathbf{b}$ - specific activity, $\mathrm{OD}_{600}$ value, $\mathrm{pH}$. Mean values relating to the same series, expressed in different letters are significantly different $(p<0.05)$ 

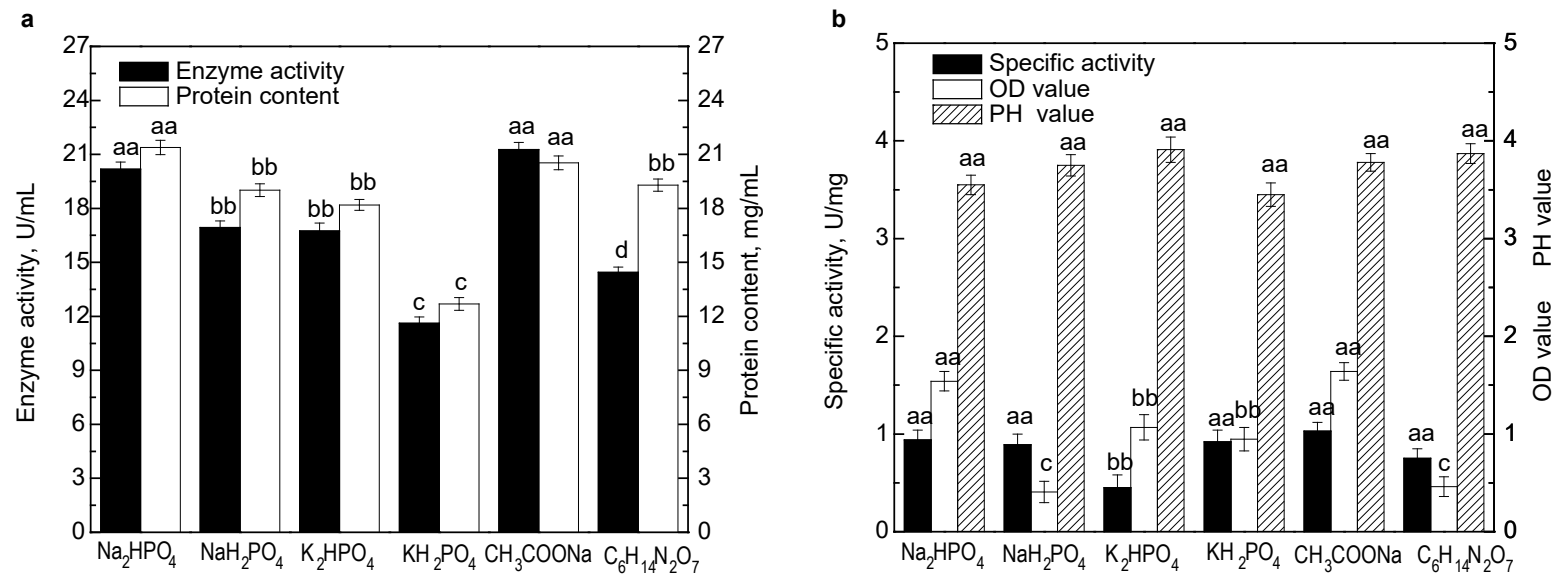

Fig. 4. The effect of different inorganic salts on CEP production by L. plantarum LP69: a - enzyme activity, protein content, $\mathbf{b}$ - specific activity, $\mathrm{OD}_{600}$ value, $\mathrm{pH}$. Mean values relating to the same series, expressed in different letters are significantly different $(p<0.05)$

partial inulin hydrolysis acted as an additional carbon source, increasing the osmotic pressure of the cells (Oliveira et al., 2012). Enzyme activity changed with an increasing inulin concentration, indicating that the expression of CEP by L. plantarum LP69 may be linked with the medium composition. These results demonstrated that suitable inulin content in the MRS medium improved both $L$. plantarum LP69 growth and levels of products.

The isomaltooligosaccharide (IMO) was added to the MRS medium at $0.1 \%, 0.3 \%, 0.5 \%, 0.7 \%$ and $0.9 \%$. As shown in Figure 3, enzyme activity and specific activity increased with an increasing concentration of the IMO, and then dropped, with a maximum at the IMO concentration of $0.5 \%$, which was 21.47 $\mathrm{U} / \mathrm{mL}, 1.12 \mathrm{U} / \mathrm{mg}$, respectively $(p<0.05)$. The protein content increased first and then decreased, and reached the maximum value of $21.24 \mathrm{mg} / \mathrm{mL}$ at the IMO concentration $0.3 \%$. In addition, the $\mathrm{OD}$ value and $\mathrm{pH}$ value were respectively taken to the maximum and minimum values at $0.5 \%$ IMO concentration. Therefore, $0.5 \%$ was selected as the optimum concentration of IMO.

Consumption of IMO can stimulate the growth of lactobacillus (Chen et al., 2011). The addition of IMO could effectively improve the CEP activity and specific activity of $L$. plantarum LP69, but a high concentration of IMO inhibited the bacterial growth and CEP production. This may be because IMO produced a large amount of glucose during metabolism (Hu et al., 2013), which inhibited bacteria proliferation and changed the composition of the medium. These results suggested that appropriate IMO content in MRS broth stimulated both $L$. plantarum LP69 growth and CEP activity.

\section{Effect of inorganic salts on L. plantarum LP69 producing CEP}

The addition of appropriate buffer salts in medium can adjust the $\mathrm{pH}$ of the growth environment and the osmotic pressure of the cells (Yao et al., 2017), which promotes the growth of bacteria and improves the level of the product (Tong et al., 2012). It can be seen from Figure 4 that when $\mathrm{Na}_{2} \mathrm{HPO}_{4}$ or $\mathrm{CH}_{3} \mathrm{COONa}$ was added to the medium, L. plantarum LP69 had higher enzyme activity, protein content, specific activity and OD value $(p<0.05)$. There was no significant change in $\mathrm{pH}$ values when different inorganic salts were added into the MRS medium $(p>0.05)$. Therefore, $\mathrm{Na}_{2} \mathrm{HPO}_{4}$ and $\mathrm{CH}_{3} \mathrm{COONa}$ were selected for further study.

The $\mathrm{Na}_{2} \mathrm{HPO}_{4}$ was added to MRS medium at $0 \%$, $0.2 \%, 0.4 \%, 0.6 \%$ and $0.8 \%$. As shown in Figure 5, by increasing the $\mathrm{Na}_{2} \mathrm{HPO}_{4}$ percentage in the medium, the enzyme activity, protein content and specific activity first increased and then decreased $(P<0.05)$, which were consistent with the trend of optical density. When the concentration of $\mathrm{Na}_{2} \mathrm{HPO}_{4}$ was $0.4 \%$, the enzyme activity, protein content and specific activity 
a

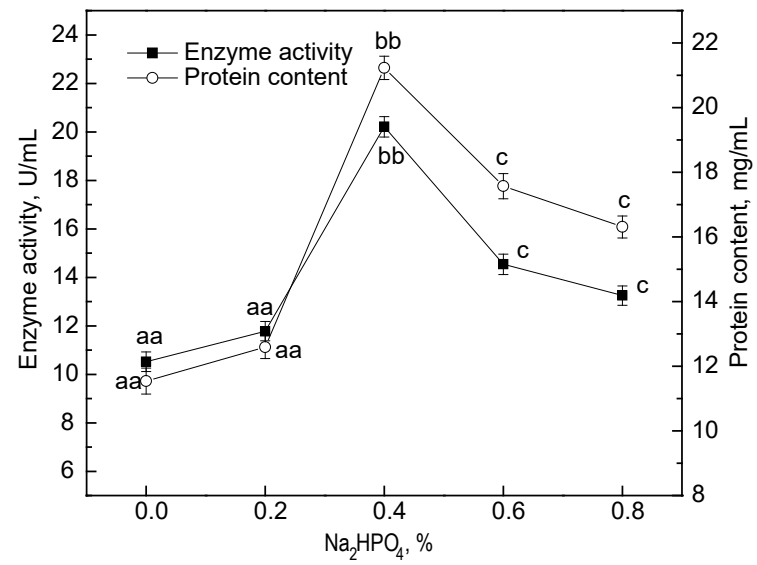

b

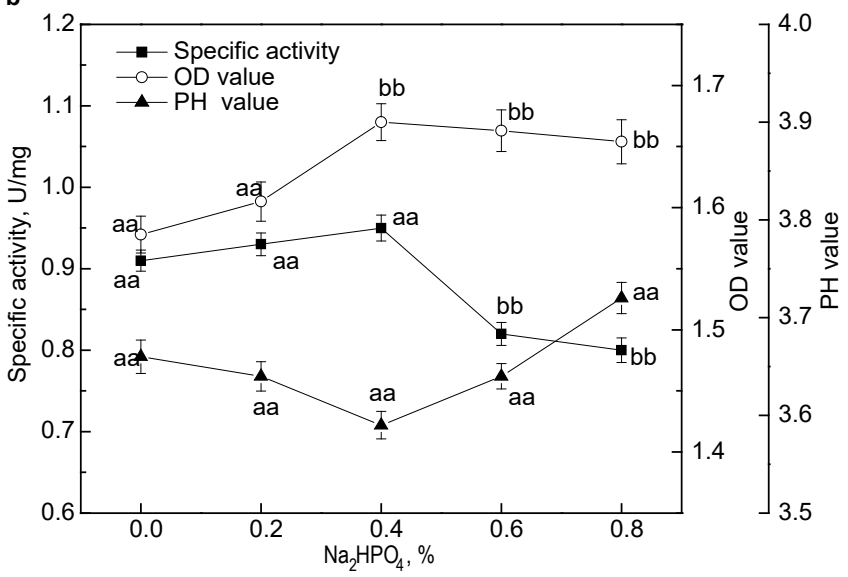

Fig. 5. The effect of $\mathrm{Na}_{2} \mathrm{HPO}_{4}$ on CEP production by L. plantarum LP69: $\mathbf{a}$ - enzyme activity, protein content, $\mathbf{b}-$ specific activity, $\mathrm{OD}_{600}$ value, $\mathrm{pH}$. Mean values relating to the same series, expressed in different letters are significantly different $(p<0.05)$

reached a maximum of $20.21 \mathrm{U} / \mathrm{mL}, 21.23 \mathrm{U} / \mathrm{mg}$, and $0.95 \mathrm{U} / \mathrm{mg}$, respectively, and $\mathrm{pH}$ reached the minimum value. Therefore, $0.4 \%$ was selected as the best concentration of $\mathrm{Na}_{2} \mathrm{HPO}_{4}$.

Fang et al. (2008) reported that $\mathrm{K}_{2} \mathrm{HPO}_{4}$ and $\mathrm{Na}_{2}$ $\mathrm{HPO}_{4}$ can greatly enhance the activity of thermoduric protease produced by $\mathrm{LAB}$, and the effect of $\mathrm{K}_{2} \mathrm{HPO}_{4}$ concentration on enzyme production is also especially remarkable. This research proved that a suitable content of $\mathrm{Na}_{2} \mathrm{HPO}_{4}$ could improve the CEP activity of
L. plantarum LP69, but an excessive concentration of $\mathrm{Na}_{2} \mathrm{HPO}_{4}$ has a negative effect on CEP production. The trend of bacterial density change was in accordance with the trend of CEP activity. These results suggest that the expression of CEP by L. plantarum LP69 and bacterial growth is probably related to the medium composition.

The $\mathrm{CH}_{3} \mathrm{COONa}$ was added to the MRS medium at $0 \%, 0.2 \%, 0.4 \%, 0.6 \%$ and $0.8 \%$. The results (Fig. 6 ) show that the enzyme activity, protein content and

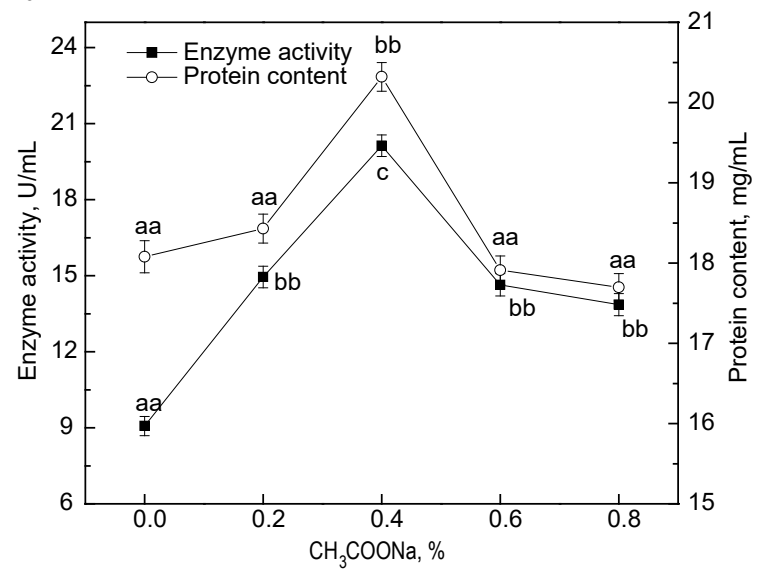

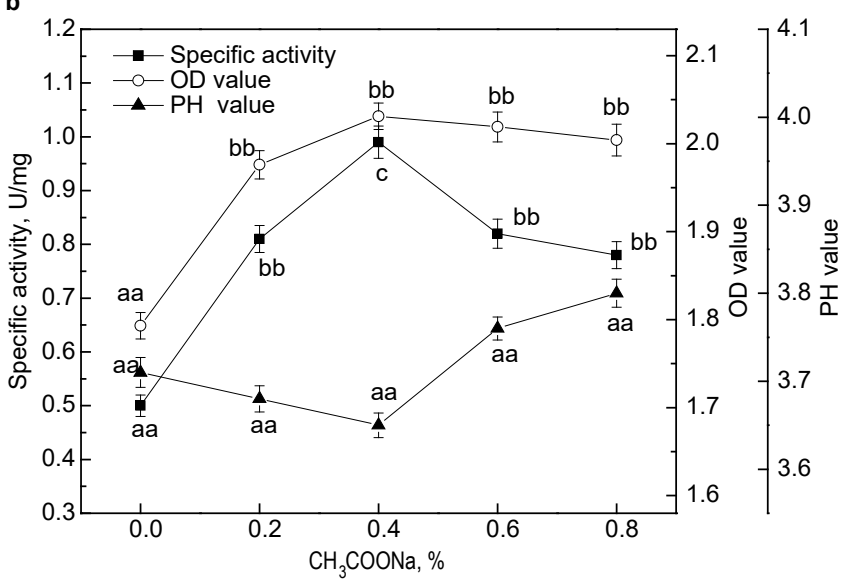

Fig. 6. The effect of $\mathrm{CH}_{3} \mathrm{COONa}$ on CEP production by L. plantarum LP69: $\mathbf{a}$ - enzyme activity, protein content, $\mathbf{b}-$ specific activity, $\mathrm{OD}_{600}$ value, $\mathrm{pH}$. Mean values relating to the same series, expressed in different letters are significantly different $(p<0.05)$ 

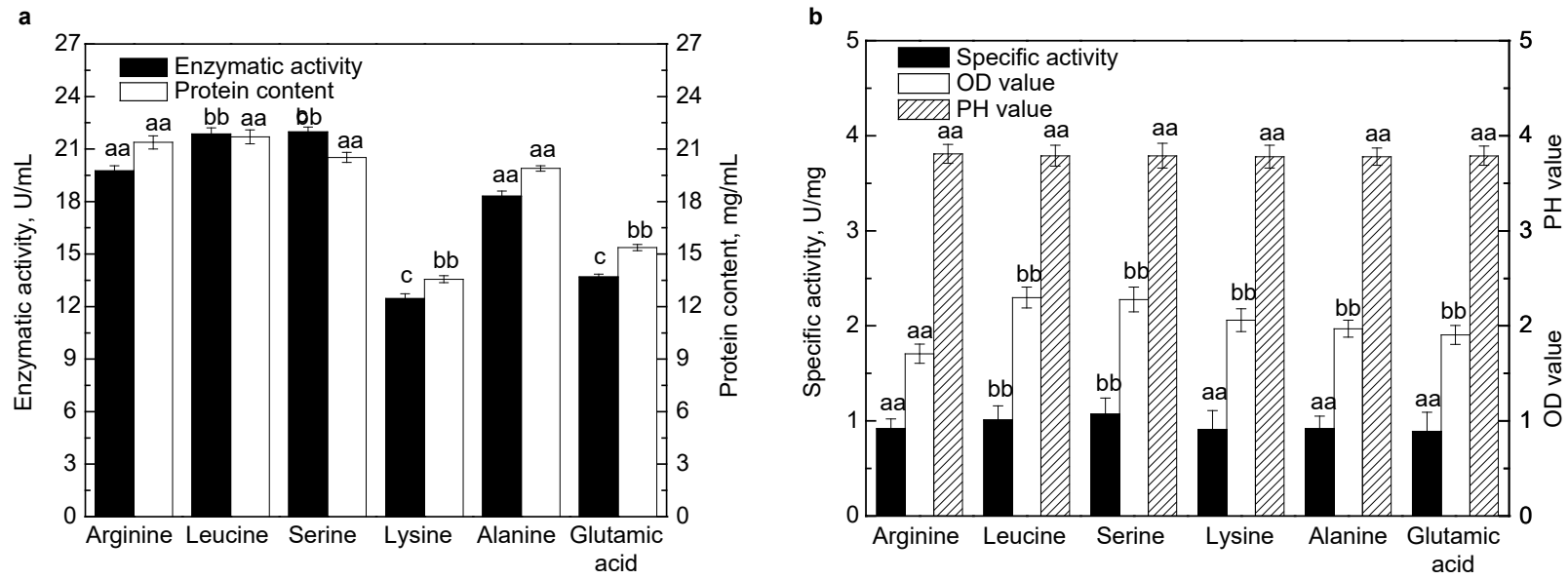

Fig. 7. The effect of different amino acids on CEP production by L. plantarum LP69: a - enzyme activity, protein content, $\mathbf{b}-$ specific activity, $\mathrm{OD}_{600}$ value, $\mathrm{pH}$. Mean values relating to the same series, expressed in different letters are significantly different $(p<0.05)$

specific activity first increased and then decreased $(P<0.05)$ with the increase in $\mathrm{CH}_{3} \mathrm{COONa}$ concentration, and all reached the highest value when the concentration of $\mathrm{CH}_{3} \mathrm{COONa}$ was $0.4 \%$, with a maximum value of $20.13 \mathrm{U} / \mathrm{mL}, 20.32 \mathrm{mg} / \mathrm{mL}, 0.99 \mathrm{U} / \mathrm{mg}$, respectively. The OD value and $\mathrm{pH}$ value also obtained good values respectively when the $\mathrm{CH}_{3} \mathrm{COONa}$ concentration was $0.4 \%$. Therefore, the $\mathrm{CH}_{3} \mathrm{COONa}$ concentration of $0.4 \%$ was selected.

$\mathrm{Wu}$ and Pan (2013) delineated that $\mathrm{CH}_{3} \mathrm{COONa}$ significantly improved the CEP activity of Lactobacillus casei DI-1 in the medium, which is in accordance with the results observed for strain LP69, but $\mathrm{CH}_{3} \mathrm{COONa}$ in a high concentration had a passive effect on proteinase activity. Meanwhile, it was found that a suitable content of $\mathrm{CH}_{3} \mathrm{COONa}$ could greatly improve the density of $L$. plantarum LP69. This study showed that medium composition and concentration could influence microbial growth and metabolite production (Li et al., 2006).

\section{Effect of amino acids on L. plantarum LP69 producing CEP}

Amino acids could induce proteinase production of bacteria. It can be seen from Figure 7 that when leucine or serine was added to the medium, L. plantarum LP69 had higher enzyme activity, specific activity and OD value $(p<0.05)$. There was no obvious change in the $\mathrm{pH}$ of medium when different amino acids were added into the MRS broth $(p>0.05)$. Therefore, leucine and serine were selected for further study.

The leucine was added to the MRS medium at 10, 15, 20, 25 and $30 \mathrm{mg} / \mathrm{L}$. As shown in Figure 8, as the leucine concentration increased, enzyme activity, protein content, specific activity and OD value first increased and then decreased $(P<0.05)$. When the concentration of leucine was $20 \mathrm{mg} / \mathrm{L}$, the enzyme activity, protein content and specific activity reached a maximum of $19.98 \mathrm{U} / \mathrm{mL}, 19.58 \mathrm{mg} / \mathrm{mL}$ and 1.02 $\mathrm{U} / \mathrm{mg}$, respectively. The OD value and $\mathrm{pH}$ value were taken to the maximum and minimum value when the leucine concentration was $20 \mathrm{mg} / \mathrm{L}$. Therefore, $20 \mathrm{mg} / \mathrm{L}$ was selected as the best concentration of leucine.

The serine was added to the MRS medium at 10, 15, 20,25 and $30 \mathrm{mg} / \mathrm{L}$. Figure 9 shows that when the serine concentration increased from $10 \mathrm{mg} / \mathrm{L}$ to $30 \mathrm{mg} / \mathrm{L}$, the enzyme activity, protein content and specific activity all first increased and then decreased $(P<0.05)$, and reached the maximum at a serine concentration of $20 \mathrm{mg} / \mathrm{L}$. The maximum values were $19.39 \mathrm{U} / \mathrm{mL}$, $20.86 \mathrm{mg} / \mathrm{mL}, 0.92 \mathrm{U} / \mathrm{mg}$, respectively. The OD value and $\mathrm{pH}$ value also indicated that $L$. plantarum LP69 grew better at $20 \mathrm{mg} / \mathrm{L}$ serine concentration. Therefore, $20 \mathrm{mg} / \mathrm{L}$ was selected as the optimum content of serine. 
a

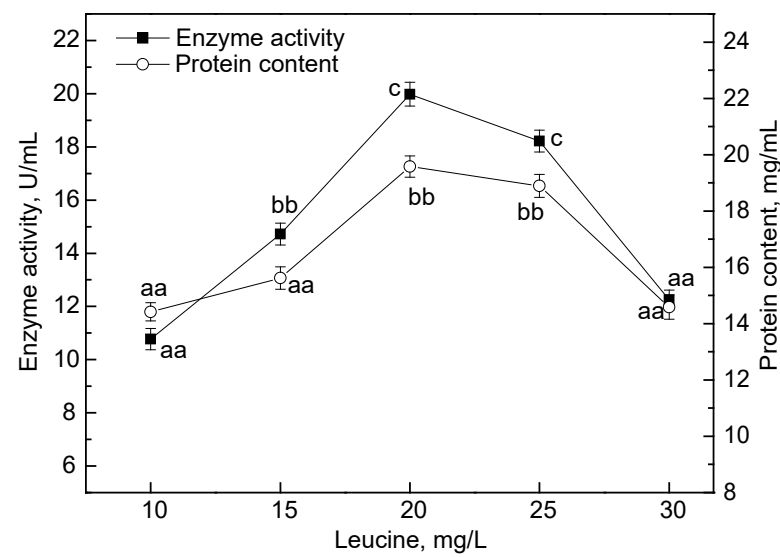

b

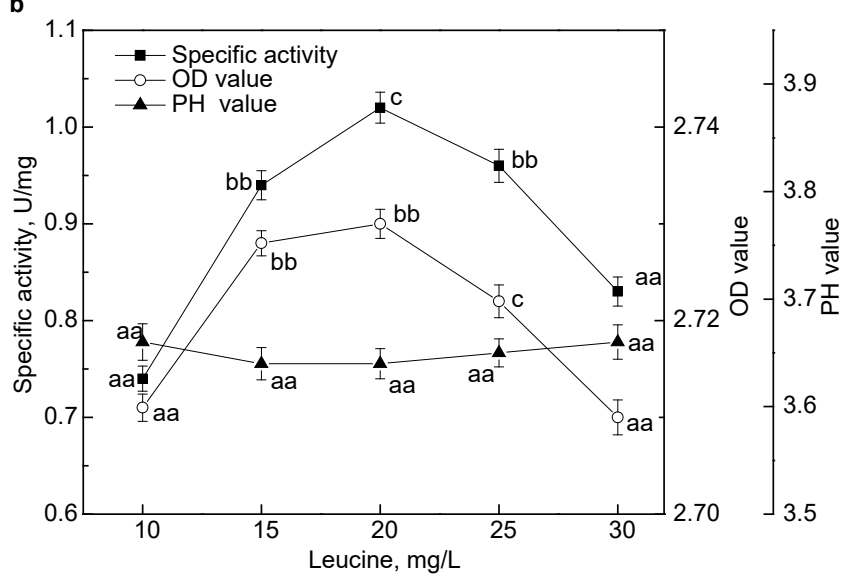

Fig. 8. The effect of leucine on CEP production by L. plantarum LP69: a - enzyme activity, protein content, $\mathbf{b}-$ specific activity, $\mathrm{OD}_{600}$ value, $\mathrm{pH}$. Mean values relating to the same series, expressed in different letters are significantly different $(p<0.05)$

a

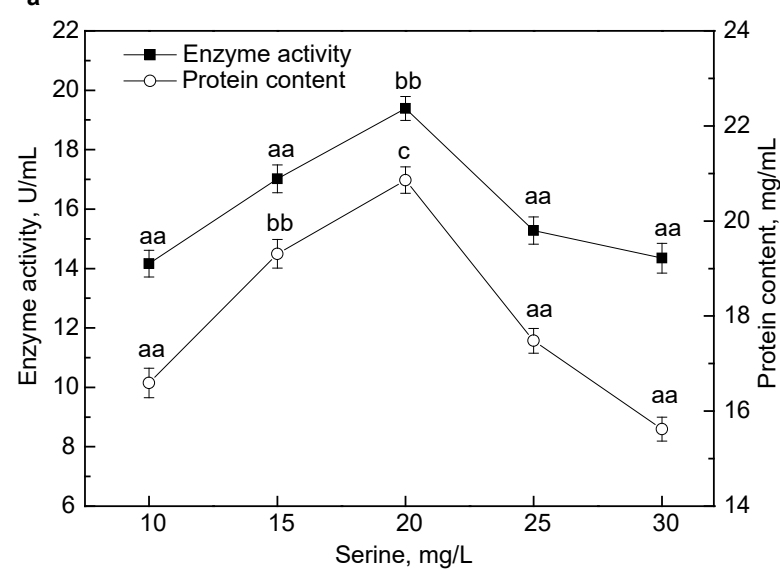

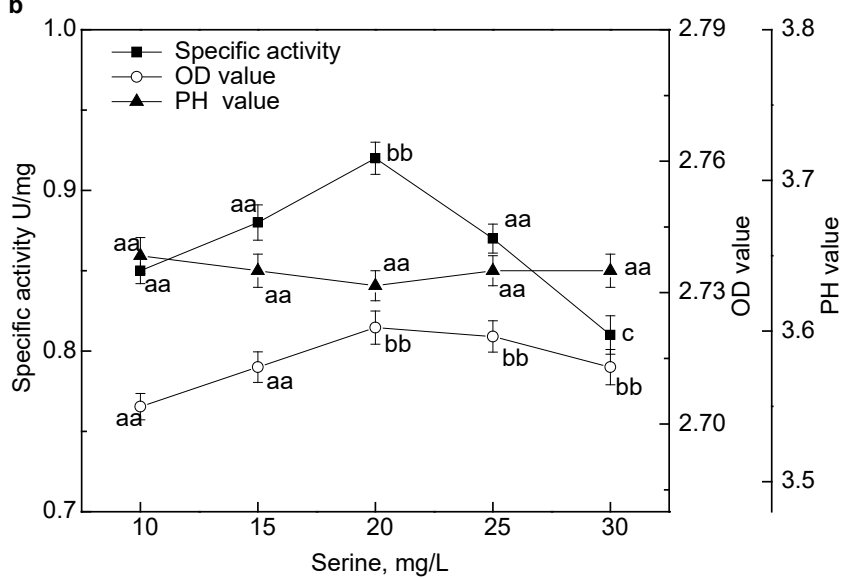

Fig. 9. The effect of serine on CEP production by L. plantarum LP69: a - enzyme activity, protein content, $\mathbf{b}$ - specific activity, $\mathrm{OD}_{600}$ value, $\mathrm{pH}$. Mean values relating to the same series, expressed in different letters are significantly different $(p<0.05)$

A study indicated that serine and leucine had remarkable promotion effects on the growth of Lactobacillus bulgaricus (An et al., 2009). The results of the present study show that serine and leucine also stimulated the growth of $L$. plantarum LP69. Fairbairn and Law (1986) reported that leucine is an effective factor to induce proteinase production. Moreover, it was found that serine had an important role in increasing the CEP activity of Lactobacillus casei DI-1 (Wu and Pan, 2013). These findings are identical with those observed for strain LP69. The excess accumulation of amino acids in turn reduced the protease synthesis, which failed to improve CEP production (Rahman et al., 2003).

\section{CONCLUSIONS}

The effect of prebiotics, inorganic salts and amino acids on the CEP production by Lactobacillus plantarum LP69 was investigated. The results showed that inulin, isomaltooligosaccharide, $\mathrm{Na}_{2} \mathrm{HPO}_{4}, \mathrm{CH}_{3} \mathrm{COONa}$, leucine and serine were superior to other selected 
Cheng, F., Chen, H., Lei, N., Zhang, M., Wan, H., Shu, G. (2019). Effect of prebiotics, inorganic salts and amino acids for cell envelope proteinase production from Lactobacillus plantarum LP69. Acta Sci. Pol. Technol. Aliment., 18(3), 269-278. http://dx.doi. org/10.17306/J.AFS.2019.0656

substances. The optimum concentration of inulin, isomaltooligosaccharide, $\mathrm{Na}_{2} \mathrm{HPO}_{4}, \mathrm{CH}_{3} \mathrm{COONa}$, leucine and serine for CEP production were $0.7 \%, 0.5 \%$, $0.4 \%, 0.4 \%, 20 \mathrm{mg} / \mathrm{L}, 20 \mathrm{mg} / \mathrm{L}$, respectively, and the maximum levels of CEP activity were obtained. These results provide a reference for further optimization of CEP-producing media of L. plantarum LP69.

\section{REFERENCES}

Agyei, D., Potumarthi, R., Danquah, M. K. (2012). Optimisation of batch culture conditions for cell-envelopeassociated proteinase production from Lactobacillus delbrueckii subsp. lactis ATCC $\left(7830^{\mathrm{TM}}\right.$. Appl. Biochem. Biotechnol., 168(5), 1035-1050. http://dx.doi. org/10.1007/s12010-012-9839-9

An, L., Lv, J. L., Li, X. H. (2009). Effects of the composites milk and amino acid on the growth of Lactobacillus bulgaricus. J. Shanxi Univ. Sci. Technol., 27(1), 65-67.

Adebola, O. O., Corcoran, O., Morgan, W. A. (2014). Synbiotics: the impact of potential prebiotics inulin, lactulose and lactobionic acid on the survival and growth of lactobacilli probiotics. J. Funct. Foods, 10, 75-84. http:// dx.doi.org/10.1016/j.jff.2014.05.010

Bradford, M. M. (1976). A rapid and sensitive method for the quantitation of microgram quantities of protein utilizing the principle of protein-dye binding. Anal. Biochem., 72, 248-254. http://dx.doi.org/10.1016/00032697(76)90527-3

Chen, H., Huang, J., Cao, B. Y., Chen, L., Song, N. (2018). Study of extraction and enzymatic properties of cellenvelope proteinases from a novel wild Lactobacillus plantarum LP69. Catalysts, 8(8), 325. http://dx.doi. org/10.3390/catal8080325

Chen, H., Ji, Z., Shu, G. W., Xing, H. (2012). Effect of probiotic lactobacillus strains on Angiotensin-I Converting enzyme inhibitory activity from fermented goat milk. Adv. Mat. Res., 531, 442-445. http://dx.doi. org/10.4028/www.scientific.net/AMR.531.442

Chen, H., Hui, Y. X., Chen, L., Wan, H. C., Shu, G. W. (2015). Effect of probiotic lactobacillus strains on antioxidant activity from fermented goat milk. Carpath. J. Food Sci. Technol., 7(2), 109-114.

Chen, H., Ji, L. Y., Shu, G. W., Li, C. N. (2011). Effect of galaeto-oligosaccharide and isomalto-oligosaccharide on growth of selected probiotics. Adv. Mat. Res., 382, 450-453. http://dx.doi.org/10.4028/www.scientific.net/ AMR.382.450
Espeche Turbay, M. B., Savoy, de G. G., Hebert, E. M. (2009). Release of the cell-envelope-associated proteinase of Lactobacillus delbrueckii subspecies lactis CRL 581 is dependent upon $\mathrm{pH}$ and temperature. J. Agric. Food Chem., 57(18), 8607-8611. http://dx.doi. org/10.1021/jf901531q

Fang, F., Ji, L. L., Zhang Y. B., Zhang, H. P., Menghebilige, (2008). Screening of thermoduric proteinase-producing lactic acid bacteria, conditions of enzyme production and properties of produced thermoduric proteinase. Food Sci., 29(10), 375-379.

Fairbairn, D. J., Law, B. A. (1986). Proteinases of psychrotrophic bacteria: their production, properties, effects and control. J. Dairy Res., 53, 139-177. http://dx.doi. org/10.1017/S0022029900024742

Hebert, E. M., Raya, R. R., De Giori, G. S. (2000). Nutritional requirements and nitrogen-dependent regulation of proteinase activity of Lactobacillus helveticus CRL 1062. Appl. Environ. Microbiol., 66(12), 5316-5321. http://dx.doi.org/10.1128/AEM.66.12.5316-5321.2000

Hammes, W. P., Hertel, C. (2006). The genera Lactobacillus and Carnobacterium. In M. Dworkin, S. Falkow, E. Rosenberg, K. H. Schleifer, E. Stackebrandt (Eds.), The Prokaryotes (pp. 320-403). New York: Springer. http:// dx.doi.org/10.1007/0-387-30744-3_10

Hebert, E. M., Raya, R. R., De Giori, G. S. (2004). Nutritional requirements of Lactobacillus delbrueckii subsp. lactis in a chemically defined medium. Curr. Microbiol., 49(5), 341-345. http://dx.doi.org/10.1007/s00284-0044357-9

Hu, Y., Ketabi, A., Buchko, A., Ganzle, M. G. (2013) Metabolism of isomaltooligosaccharides by Lactobacillus reuteri and bifidobacteria. Lett. Appl. Microbiol., 57, 108-114. http://dx.doi.org/10.1111/lam.12076

Li, Y. H., Liu, B., Zhao, Z. B., Bai, F. W. (2006). Optimization of culture conditions for lipid production by rhodosporidium toruloides. Chinese J. Biotechnol., 22(4), 650-656. http://dx.doi.org/10.1016/S1872-2075 (06)60050-2

Laloi, P., Atlan, D., Blanc, B., Gilbert, C., Portalier, R. (1991). Cell-wall-associated proteinase of Lactobacillus delbrueckii subsp. bulgaricus CNRZ 397: differential extraction, purification and properties of the enzyme. Appl. Microbiol. Biotechnol., 36, 196-204. http:// dx.doi.org/10.1007/bf00164419

Ngo, L. T. A., Pham, T. L., Le, V. V. M. (2008). Purification of endopolygalacturonase from submerged culture of Aspergillus awamori L1 using a two-step procedure: Enzyme precipitation and gel filtration. Int. Food Res. J., 15, 135-140. 
Oliveira, R. P. S., Perego, P., Oliveira, M. N., Converti, A. (2012). Effect of inulin on the growth and metabolism of a probiotic strain of Lactobacillus rhamnosus in coculture with Streptococcus thermophilus. LWT - Food Sci. Technol., 47, 358-363. http://dx.doi.org/10.1016/j. lwt.2012.01.031

Paloma, D. F., Nieves, C., Agustín, O., Oswaldo, H. H., Javier, M. F. (2019). Effect of selected prebiotics on the growth of lactic acid bacteria and physicochemical properties of yoghurts. Int. Dairy J., 89, 77-85. http:// dx.doi.org/10.1016/j.idairyj.2018.09.003

Ren, X. F., Pan, D. D., Zeng, X. Q., Zhao, Z. W., Zhu, D. D. (2014). Optimization of culture conditions and fermentation conditions for Cell Wall Proteinase (CEP) production by Lactobacillus acidophilus. J. Chinese Inst. Food Sci. Technol., 14(2), 146-153.

Rahman, R. N. Z. R. A., Basri, M., Salleh, A. B. (2003). Thermostable alkaline protease from Bacillus stearothermophilus F1; nutitional factors affecting protease production. Ann. Microbiol., 53, 199-210.

Samartsev, A. A., Astapovich, N. I., Novik, G. I. (2000). Production of cell-wall-bound proteinases in bifidobacterium adolescentis 94-BIM. Microbiology, 69(6), 655658. http://dx.doi.org/10.1023/a:1026697906562

Scolari, G., Vescovo, M., Zacconi, C., Vescovi, F. (2006). Extraction and partial characterization of proteolytic activities from the cell surface of Lactobacillus helveticus
Zuc2. J. Dairy Sci., 89(10), 3800-3809. http://dx.doi. org/10.3168/jds.s0022-0302(06)72421-3

Tsakalidou, E., Anastasiou, R., Vandenberghe, I., Beeumen, J. V., Kalantzopoulos, G. (1999). Cell-wall-bound proteinase of Lactobacillus delbrueckii subsp. lactis ACADC 178: Characterization and specicity for $\beta$-Casein. Appl. Environ. Microbiol., 65(5), 2035-2040. PMID: 10223997.

Tong, S. S., Xie, L. X., Xu, L., Hu, T., Liu, P. (2012). Culture medium optimization of Lactobacillus plantarum for bacteriocin production. Modern Food Sci. Technol., 28(2), 152-155.

Wu, Z., Pan, D. D. (2013). Optimization of culture medium for the production of cell envelope proteinase by Lactobacillus Casei DI-1. J. Chinese Inst. Food Sci. Technol., 13(2), 108-115.

Wu, W. Q., Wang, L. L., Zhao, J. X., Zhang, H., Chen, W. (2019). Research progress on physiological characteristics and health benefits of Lactobacillus plantarum. Food Ferm. Indust., 45(1), 1-13. http://dx.doi.org/10.13995/j. cnki.11-1802/ts.019602

Yao, G. Q., Zhang, X. M., Gao, Z. M., Zhao, Y. X., Sun, T. S., Zhang, H. P. (2017). Optimization of enrichment medium and high cell density cultivation of Lactobacillus reuteri IMAU10240. Food Sci., 38(14), 97-105. http:// dx.doi.org/10.7506/spkx1002-6630-201714015 